that spawn out of town shopping and recreational facilities. Local shops and schools cannot compete and are forced to close. People without cars must either put up with shrinking local provision or invest in a car. Once bought, a car tends to be used for other journeys.

This trend is not universal. In Dutch towns and cities up to half of all trips are made by bicycle and the proportion is growing. ${ }^{7}$ The Dutch government's strong support for cycling, rather than the Netherlands" Hat terrain, is responsible. Between 1975 and 1985 it spent $£ 230$ m building cycle routes, parking areas, and facilities at railway stations.

The BMA's recommendations are far from new; they have been made by cycling bodies, environmentalists, and enlightened planners for years. They include more cycling lanes, an integrated system of cycling paths, priority for cyclists and pedestrians over motorists, traffic restraint, and better access for cycles on trains. As the report says, it is mysterious how policy makers in Britain have managed repeatedly to overlook the benefits of encouraging more cycling.

Cycling has become a public health issue and one on which doctors can set an example-as they did on cigarette smoking. Like the professor of public health in Newcastle ${ }^{8}$ those of us who can should abandon our cars. It could inspire a new slogan: "Think first; most doctors go by bike."

Assistant editor, $B M \mathcal{F}$

FIONA GODLEE

1 BMA. Cycling towards health and safety. Oxford, New York: Oxford University Press, 1992.

2 Williams R. De sanitate urbanorum. BMF 1979;ii:1617-22.

3 Morris JN, Clayton DG, Everitt MG, Semmence AM, Burgess EH. Exercise in leisure time: coronary attack and death rates. Br Heart $\mathcal{f}$ 1990;63:325-43.

4 Robertson HK. Heart disease in life long cyclists. BMF 1977;ii:1635-6.

5 Public Health Alliance. Health on the move: policies for health promoting transport. The policy statement of the Transport and Health Study Group. Birmingham: Public Health Alliance, 1991.

6 Banister C. Existing travel patterns: the potential for cycling. In: Cycling and the healthy city. London: Friends of the Earth, 1990:20-8.

7 Lowe M. Cycling into the future. In: Browne LR, ed. State of the world 1990. A Worldwatch Institute report on progress towards a sustainable society. New York: W W Norton, 1990.

8 Bhopal R. One car down. BMF 1992;304:451-2.

\title{
Photodynamic therapy for cancer
}

\section{Still awaiting rigorous evaluation}

That certain dyes, activated by light, have biological effects has been known for a century. ${ }^{1}$ In 1903 three patients with skin cancer became the first to be treated by photodynamic therapy, with topical eosin and a combination of sunlight and artificial light being used. ${ }^{2}$ The recent surge in clinical and research interest stems from the work of Dougherty in the '70s, which showed that the treatment can selectively necrose tumours

The treatment entails injecting patients with a photosensitiser, which is partially retained in tumours over a period of 48-72 hours by a complex pharmacokinetic process. The most commonly used agents are haematoporphyrin derivative and its more purified form, photofrin. Two days later the drug within the tumour is activated by laser light (usually tuned at $630 \mathrm{~nm}$, red colour) to release singlet oxygen, a cytotoxic species that destroys the tumour by acting directly on tumour cells and indirectly through changes in tumour vasculature. ${ }^{+5}$

As photodynamic therapy depends on light which has a limited penetration in living tissues the depth of necrosis does not exceed $5-10 \mathrm{~mm}$. It therefore follows that for treatment to be curative it should be applied to small and thin lesions. Despite this, most research has concentrated on treating advanced tumours, and only recently have attempts been made to treat early lesions. In a recent Japanese multicentre study photodynamic therapy produced complete remission in all 78 patients with tumours of the stomach, lung, and bladder of less than $1 \mathrm{~cm}$ diameter. ${ }^{6}$ Other studies have reported similar results for various early tumours but have been criticised for their small numbers and lack of randomisation.

In some cases, early tumours metastasise readily to regional lymph nodes, in which case surgery remains the best treatment because of its ability to deal with lymphatic drainage. ${ }^{7}$ Nevertheless, photodynamic therapy may have a role in the curative treatment of small tumours in selected patients, particularly those with in situ lesions. Furthermore, its use may have even greater potential in treating residual microscopic deposits left behind after what seems to have been curative surgery. ${ }^{8}$ In these cases photodynamic therapy is delivered intraoperatively to the tumour bed after excision of the primary tumour. Whether this adjuvant use has any effect on local recurrence after ostensibly curative surgery for colorectal cancer is currently the subject of a phase III study. ${ }^{9}$

Although photodynamic therapy is most suitable for small lesions due to its lack of penetration, it also seems to palliate advanced and recurrent tumours effectively by reducing their bulk. ${ }^{10}$ Interestingly, this occurs even in lesions that have failed to respond to conventional modalities. Among its advantages, photodynamic therapy can be used to treat lesions accessible to light through the endoscopic, laparoscopic, and percutaneous (ultrasonically guided) routes, making it less invasive than some other forms of treatment. In addition, its action is relatively selective because of the higher retention of photosensitiser in tumours than in normal tissue and accurate targeting of the activating light. Healing of destroyed tissue occurs by regeneration, resulting in good cosmetic and functional results. The treatment is nontoxic, causes minimal morbidity, and hence is good for palliation in patients with terminal conditions such as inoperable malignant dysphagia. ${ }^{11}$

Its main drawback is skin photosensitivity, which lasts for up to eight weeks. During this period patients are advised to stay out of sunlight to avoid developing sunburn. Furthermore, some damage, usually minimal, may occur to the surrounding normal tissues. Another drawback is that laser sources are cumbersome; difficult to operate, requiring specialist training; and expensive to run. To surmount some of these disadvantages research is being directed at finding better light sources and photosensitisers. ${ }^{12}$

More than 15 years have elapsed since photodynamic therapy in its present form was first used clinically and over 10000 patients have been treated. Because reports of its use have rarely risen above the level of anecdote it must still be considered as a research tool. This may change with several prospective controlled trials recently begun in the United States and Europe to compare photodynamic therapy with other established modalities in the treatment of solid tumours. Among these are studies comparing photodynamic therapy with neodymium YAG (yttrium aluminium garnet) laser treatment in oesophageal and lung cancer, and endoscopic resection of papillary bladder cancer with and without photodynamic therapy. These studies should help to clarify 
the role of photodynamic therapy in the management of cancer.

A MUTAZ ABULAFI Research Fellow NORMAN S WILLIAMS

Surgical Unit, Royal London Hospital, Professor of Surgery London E1 1BB

1 Marcacci A. Sur l'action des alkaloides dans le regne vegetal et animal. Archives Italiennes de Biologie $1888 ; 9: 2-4$.

2 Von Tappeiner H, Jesionek A. Theraputischen Versuche mit fluorescierenden Stoffen. Münchener Medizinische Wochenschrift 1903;47:2042-4.

3 Dougherty TJ, Grindey GB, Fiel R, Weishaupt KR, Boyle DG. Photoradiation therapy. II. Cure of animal tumors with hematoporphyrin and light. F Natl Cancer Inst 1975;55:115-9.

4 Hilf R, Smail DB, Murant RS, Leaky PB, Gibson SL. Hematoporphyrin derivative-induced photosensitivity of mitochondrial succinate dehydrogenase and selected cytosolic enzymes of R3230AC mammary adenocarcinomas of rats. Cancer Res 1984;44:1483-8.
5 Henderson BW, Waldow SM, Mang TS, Potter WR, Malone PB, Dougherty TJ. Tumor destruction and kinetics of tumor cell death in two experimental mouse tumors following photodynamic therapy. Cancer Res 1985;45:572-6.

$6 \mathrm{Kato} \mathrm{H}$, Kito T, Furuse K, Sakai E, Ito K, Mimura S, et al. Photodynamic therapy in the early treatment of cancer. Gan To Kagaku Ryoho 1990;17:1833-8.

7 Inoue $\mathrm{K}$, Tobe T, Kan N, Nio Y, Saki M, Takeuchi E, et al. Problems in the definition and treatment of early gastric cancer. Br $\mathcal{F}$ Surg 1991;78:818-21.

8 DeLaney TF, Sindelar W, Smith P, Friauf W, Pass H, Russo A, et al. Initial experience with photodynamic therapy for intraperitoneal carcinomatosis. In: Sharp F, Mason W, Leake RE, eds. Ovarian cancer. Biological and therapeutic challenges. London: Chapman and Hall Medical 1990:371-80.

9 Abulafi AM, Allardice JT, Dean R, Grahn MF, Williams NS. Adjunctive intraoperative photodynamic therapy for colorectal cancer. Gut 1991;32(suppl): 12 .

10 Dougherty TJ, Lawrence G, Kaufman JH, Boyle DG, Weishaupt KR, Goldfrab A. Photoradiation in the treatment of recurrent breast carcinoma. $\mathcal{F}$ Natl Cancer Inst 1979;62:231-7.

11 Allardice JT, Grahn MF, Ilinicic L, Swain CP, Williams NS. Photodynamic therapy for malignant dysphagia. Brf Surg 1989;76:1345

12 Ris HB, Altermat HJ, Inderbitzi R, Hess R, Nachbur B, Stewart JCM, et al. Photodynamic therapy with chlorins for diffuse malignant mesothelioma: initial clinical results. $\mathrm{Br}$ f Cancer 1991;64:1116-20.

\section{Forward dermatology}

\section{Genes looking for diseases}

Much has been written about the importance and power of reverse genetics or what is now called positional cloning. ${ }^{1}$ Pedigrees of patients with a pathological phenotype are identified, linkage analysis is performed with DNA probes that detect polymorphisms, and with luck and skill the gene responsible for the pathological phenotype is identifiedfrom map position of a particular pathological phenotype to genotype without biochemistry. Once the gene is cloned, however, the biochemistry begins: witness the struggle to explain the phenotypic abnormalities of cystic fibrosis from the isolated gene. ${ }^{2}$

An alternative and complementary approach now exists, which, rather than going from pathological grouping to map position to gene, takes advantage of the ability to mutate DNA sequences in vitro and to reintroduce these sequences into experimental animals. This strategy relies on the rapid accumulation of data on the nucleic acid sequences of "orphan" DNA, whose phenotypic function is only poorly understood. Now where there is a gene there is a mutation, and where there is a mutation there is a disease. The problem in this instance is therefore "have gene, need phenotype." Two examples from dermatology, one probably solved and one just beginning, illustrate these alternative approaches.

Over the past 10 years genes coding for epidermal keratin have been cloned, antibodies raised, and gene expression studied in various diseases. ${ }^{3}$ None of these studies, however, has answered the fundamental question of what the keratin molecules do and what would happen to the phenotype of an animal if the keratins were mutated. The new experimental approach is quite clear. What disease do we invent (or rediscover) if we mutate keratin genes? It was this sort of experiment that Fuchs et al performed. ${ }^{+}$They took a keratin 14 gene, mutated it in vitro, placed it inside transgenic mice, and raised progeny that exhibited the phenotypic abnormalities associated with some cases of epidermolysis bullosa. They went on to look at a patient with a particular variant of epidermolysis bullosa and showed that the clumping of keratin filaments in the patient resembled the findings in their mice. A few months after the publication of this paper Epstein's group, who had used conventional positional cloning, reported a point mutation in the keratin 14 gene in some kindreds with epidermolysis bullosa. ${ }^{5}$

Retinoid receptors provide the second example. The first member of the nuclear class of retinoic acid receptors was cloned four years ago. It was shown to be a member of a previously described nuclear receptor family, the steroid- thyroid receptor superfamily, which includes the receptors for adrenal steroids, triiodothyronine, and vitamin D. ${ }^{67}$

Since the original cloning nearly 20 different isoforms of nuclear retinoic acid receptor have been identified. The degree of conservation of structure of these receptors in various species and the tightly controlled expression of the receptors suggest that they are important in skin physiology. Strong circumstantial evidence that these receptors will be associated with disease is provided by the fact that many of the related receptors, such as those for androgens, vitamin $\mathrm{D}$, and thyroid hormones, are associated with distinct clinical states namely, androgen insensitivity, vitamin D resistant rickets, and thyroid insensitivity respectively. ${ }^{8-10}$ Several groups are therefore using the forward approach to make transgenic mice with mutations in different members of the retinoid receptors or to use the related technique of homologous recombination, which replaces the normal allele with a defective one. ${ }^{11}$

This may all seem rather frustrating to clinicians; scientists seem able to make disease at will whereas the poor clinicians have to sift through thousands of patients to find the odd phenotype that with a little luck and access to a molecular biology laboratory may turn out to be a home for an orphan $\dot{\delta}$ gene. Nevertheless, mice are not humans, and the true clinical

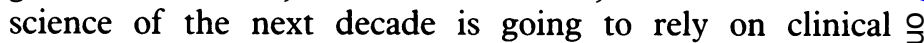
observation, a knowledge of which genes are looking for N diseases, and access to DNA facilities to follow our hunches. Truly forward dermatology.

Senior Lecturer,

JONATHAN REES

University Department of Dermatology,

Royal Victoria Infirmary,

Newcastle upon Tyne NE1 4LP

Weatherall DJ. The new genetics and clinical practice. 3rd ed. Oxford: Oxford University Press, 1991.

2 Welsh MJ. Acidification indication. Nature 1991;352:23-4.

3 Fuchs E. Keratins as biochemical markers of epithelial differentiation. Trends Genet 1988;4:277-81.

4 Vassar R, Coulombe P, Degenstein L, Albers R, Fuchs E. Mutant keratin expression in transgenic mice causes marked abnormalities resembling a human genetic disease. Cell 1991;64:365-80.

5 Bonifas J, Rothman A, Epstein E. Linkage of epidermolysis bullosa simplex to probes in the region of keratin gene clusters on chromosomes 12q and 17q. F Invest Dermatol 1991;96:550.

6 Petkovich M, Brand N, Krust A, Chambon P. A human retinoic acid receptor which belongs to the family of nuclear receptors. Nature 1987;330:444-50

7 Evans RM. The steroid and thyroid receptor superfamily. Science 1988;240:889-95.

8 Lubahn DB, Brown TR, Simental JA, Higgs HN, Migeon CL, Wilson EM, et al. Sequence of the intron/exon junctions of the coding region of the human androgen receptor gene and identification of a point mutation in a family with complete androgen insensitivity. Proc Natl Acad Sci USA 1989;86:9534-8.

9 Ritchie H, Hughes M, Thompson E, Malloy PJ, Hockburg Z, Feldman D, et al. An ochre mutation in the vitamin D receptor gene causes hereditary 1,25-dihydroxyvitamin D3 resistant rickets in three families. Proc Natl Acad Sci USA 1989;86:9783-7.

10 Sakurai A, Takeda K, Ain K, Ceccarelli P, Nakai A, Seino S, et al. Generalised resistance to thyroid hormone associated with a mutation in the ligand binding domain of the human thyroid receptor. Proc Natl Acad Sci USA 1989;86:8977-81.

11 Rossant J. Manipulating the mouse genome; implications for neurobiology. Neuron 1990;2:323-4 